\title{
STYDY ON THE PROTECTED AND UNPROTECTED CULTURE OF TULIPS IN ARGEȘ COUNTY
}

\author{
Florina Uleanu ${ }^{1, *}$, Liviu Ionuț Bălăuță ${ }^{2}$, Mihaela Ileana Oprea ${ }^{1}$ \\ ${ }^{1}$ University of Pitesti, Târgul din Vale Street, no 1, Piteşti, România \\ 2 I.C.D.P. Pitești-Mărăcineni, Argeș, România
}

Current Trends in

Natural Sciences

\begin{abstract}
The aim of this paper was to observ the differences between tulips cultivated in a solarium with the possibility of heating and outside on arable land. The biological material analyzed was represented by 2 cultivars of tulips: 'Irene Parrot' and 'Winter Parrot'. The study was conducted in Purcăreni, Argeș county. Observations, measurements and determinations were performed, the analyzed characters being the following: the height of the floral stem, the number of branches, the lenght and width of the leaves, the number of leaves, the lenhgt of the floral cup, the diameter of the floral cup. The low light conditions during the solar culture period greatly influence the increase in height of the studied cultivars, as well as the size and number of leaves, wich are lower than in the field culture. Regarding the characteristics of the floral cup, the negative influence of the low light conditios during the solar culture period is observed.
\end{abstract}

Keywords: culture, field, tulips, study, solar.

\section{INTRODUCTION}

The tulip (Tulipa gesneriana L.) is an important ornamental bulbous plant belongs to the family Liliaceae. Tulip cultivation is done for decorating different categories of green spaces, but also for growing pots and as cut flowers (Toma, 2009). The flowers in a wide range of shapes and colors are very attractive and elegant. Their consumption has increased in most of spiritual and traditional events like Christmas, Valentine'Day, Mother's Day and Happy New Year festivities (Ahmad et al., 2014, Bashir et al., 2018). Tulip blooms take place in spring, when the bulbs are planted in the field. In the case of protected crops, flowers can be obtained 10-20 days in advance, depending on the variety (Selaru, 2007).

The aim of the experiment was to determine the most efficient cultivation system for obtaining valuable morphological properties in 2 tulip cultivars which belong to the Parrot group. The Parrot tulips are spectacular through tepals and color combination (Oprea et al., 2012). The varieties of this group are also suitable for forced cultivation (Cantor and Gheorghita, 2011).

\section{MATERIALS AND METHODS}

The experiment took place in a solarium with the possibility of heating $(70 \times 8 \mathrm{~m})$ and on arable land (50x 8m), în Micești, Argeş. The biological material analyzed was represented by 2 cultivars of Tulipa gesneriana: 'Irene Parrot' and 'Winter Parrot'. 


\begin{tabular}{|c|c|}
\hline \multicolumn{2}{|c|}{$\begin{array}{c}\text { Current Trends in Natural Sciences } \\
\text { Vol. 9, Issue 18, pp. 163-170, } 2020 \\
\text { https://doi.org/10.47068/ctns.2020.v9i18.022 }\end{array}$} \\
\hline $\begin{array}{l}\text { Current Trends in Natural Sciences (on-line) } \\
\text { ISSN: 2284-953X } \\
\text { ISSN-L: 2284-9521 }\end{array}$ & $\begin{array}{r}\text { Current Trends in Natural Sciences (CD-Rom) } \\
\text { ISSN: } 2284-9521 \\
\text { ISSN-L: 2284-9521 }\end{array}$ \\
\hline
\end{tabular}

The soil was a mixture of garden soil and sand (50:50). In the field, planting tulip bulbs was done manually, in the first half of october, in bands of 6 rows, at a depth of 7-8 $\mathrm{cm}$ and a distance between bulbs of $5 \mathrm{~cm}$. The field was irrigated by sprinkling. In the solarium, the bulbs were planted in the first half of november, at the same distances between bulbs in a row and the same depth, the acces roads being $50 \mathrm{~cm}$. The 560 square meter solarium was heated with the help of an installation that used as a source of fuel the pellets resulting from the compaction of the vegetal materials. A temperature of $14^{\circ} \mathrm{C}$ was ensured. Care works specific to field or solar were carried out.

Observations, measurements and determinations were performed, the analyzed characters being the following:

- the height of the floral stem;

- the number of branches;

- the length and width of the leaves;

- the number of leaves;

- the length of the floral cup;

- the diameter of the floral cup.

The experience was bifactorial, the variable factors being the genotype and the type of culture.

Factor A-Genotype:

A1 - Cultivar 'Irene Parrot';

A2 - Cultivar 'Winter Parrot';

Factor B - Culture type:

B1 - Heated solar culture;

B2 - Field culture.

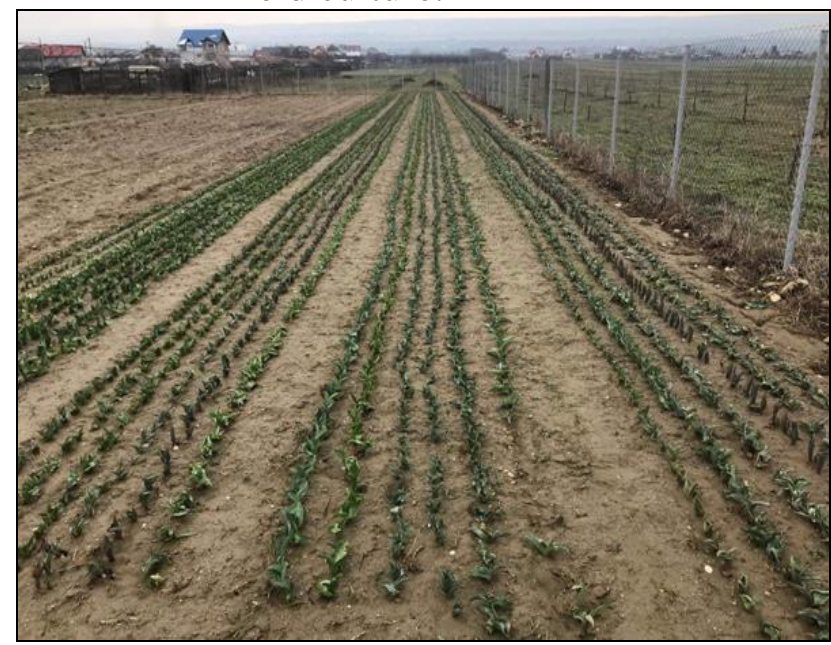

Figure 1. Field culture

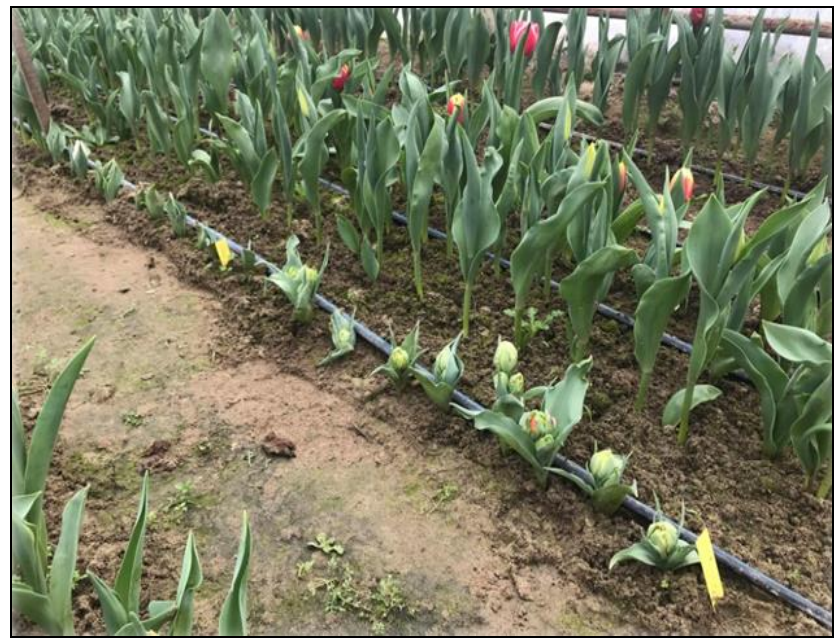

Figure 2. Heated solar culture

Experimental variants:

V1- 'Irene Parrot' in field;

V2- 'Winter Parrot' in field;

V3- 'Irene Parrot' in solarium;

V4- 'Winter Parrot' in solarium. 


\section{Current Trends in Natural Sciences}

Vol. 9, Issue 18, pp. 163-170, 2020

https://doi.org/10.47068/ctns.2020.v9i18.022

Current Trends in Natural Sciences (on-line)

ISSN: 2284-953X

ISSN-L: 2284-9521

Current Trends in Natural Sciences (CD-Rom)

ISSN: 2284-9521

ISSN-L: 2284-9521

\section{RESULTS AND DISCUSSIONS}

Tle low light conditions during the solar culture period greatly influence the increase in height of the culivars studied.

At the time of harvest, 'Winter Parrot' recorded the lowest stem height $(11.6 \mathrm{~cm})$ in the solarium crop and the higest stem height $(22.7 \mathrm{~cm})$ in the field crop (Figure 3, Figure 4).

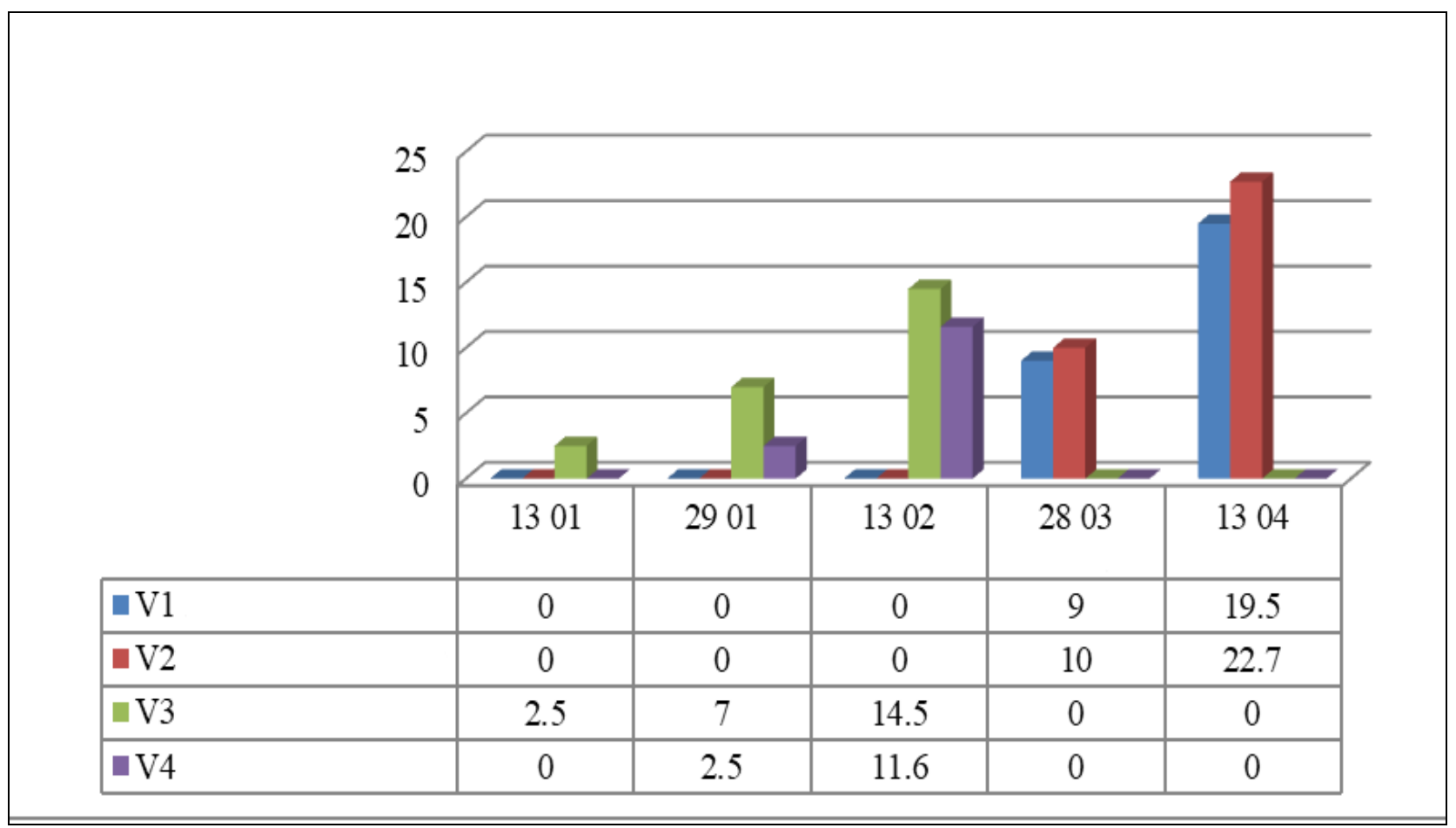

Figure 3. The height of the floral stem

a)

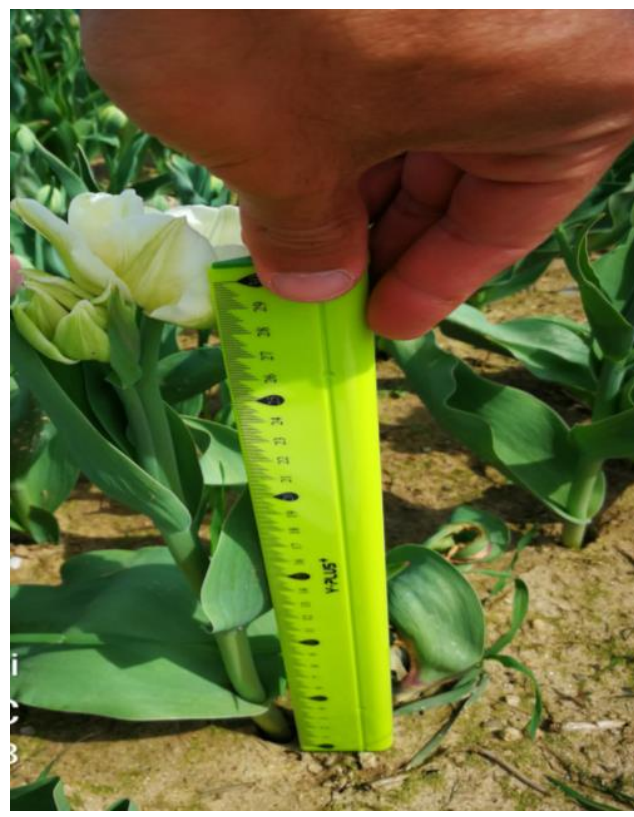

Figure 4. Measuring the height of the floral stems in the field (a) and in the solarium (b)

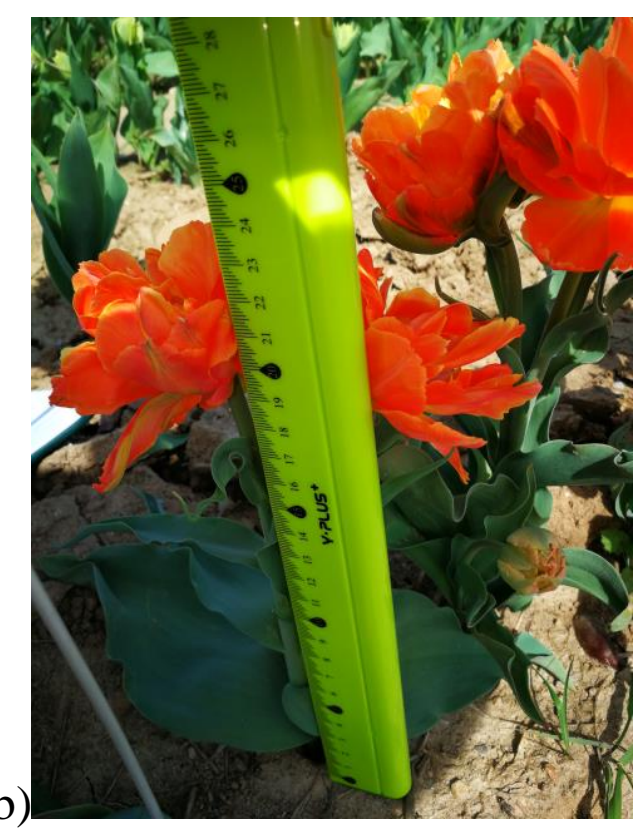




\section{Current Trends in Natural Sciences}

Vol. 9, Issue 18, pp. 163-170, 2020

https://doi.org/10.47068/ctns.2020.v9i18.022

Current Trends in Natural Sciences (on-line)

ISSN: 2284-953X

Current Trends in Natural Sciences (CD-Rom)

ISSN: 2284-9521

ISSN-L: 2284-9521

ISSN-L: 2284-9521

Regarding the number of branches/plant, 'Irene Parrot' recorded the higest average value of 2,1 (V3), compared to 1,9 (V1) branches/plant, a value recorded in the same cultivar in unprotected crops (Figure 5).

Comapared to 'Winter Parrot' (Figure 6 a), 'Irene Parrot' can have more branches (Figure 6 b).

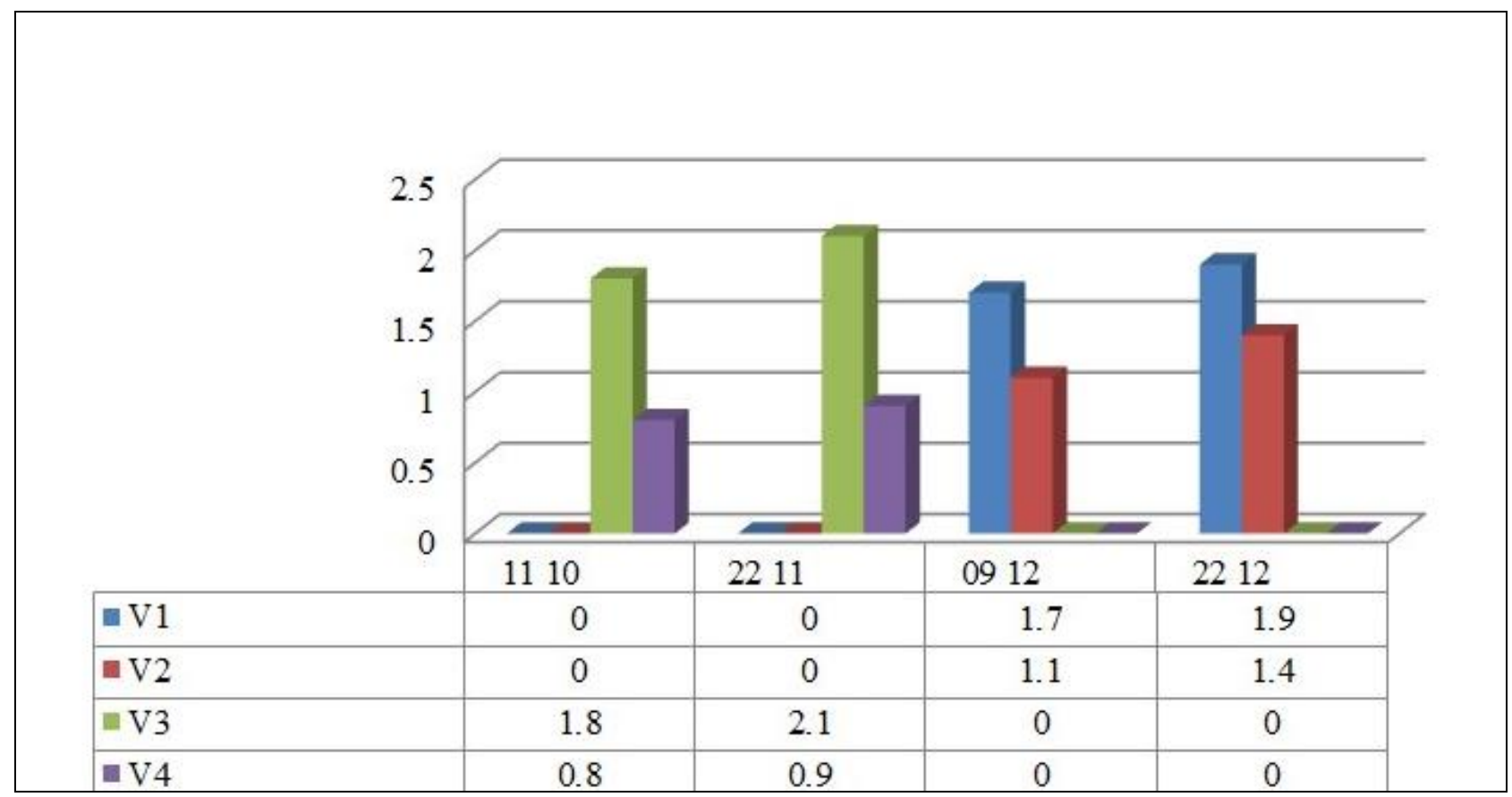

Figure 5. The number of branches in the studied cultivars
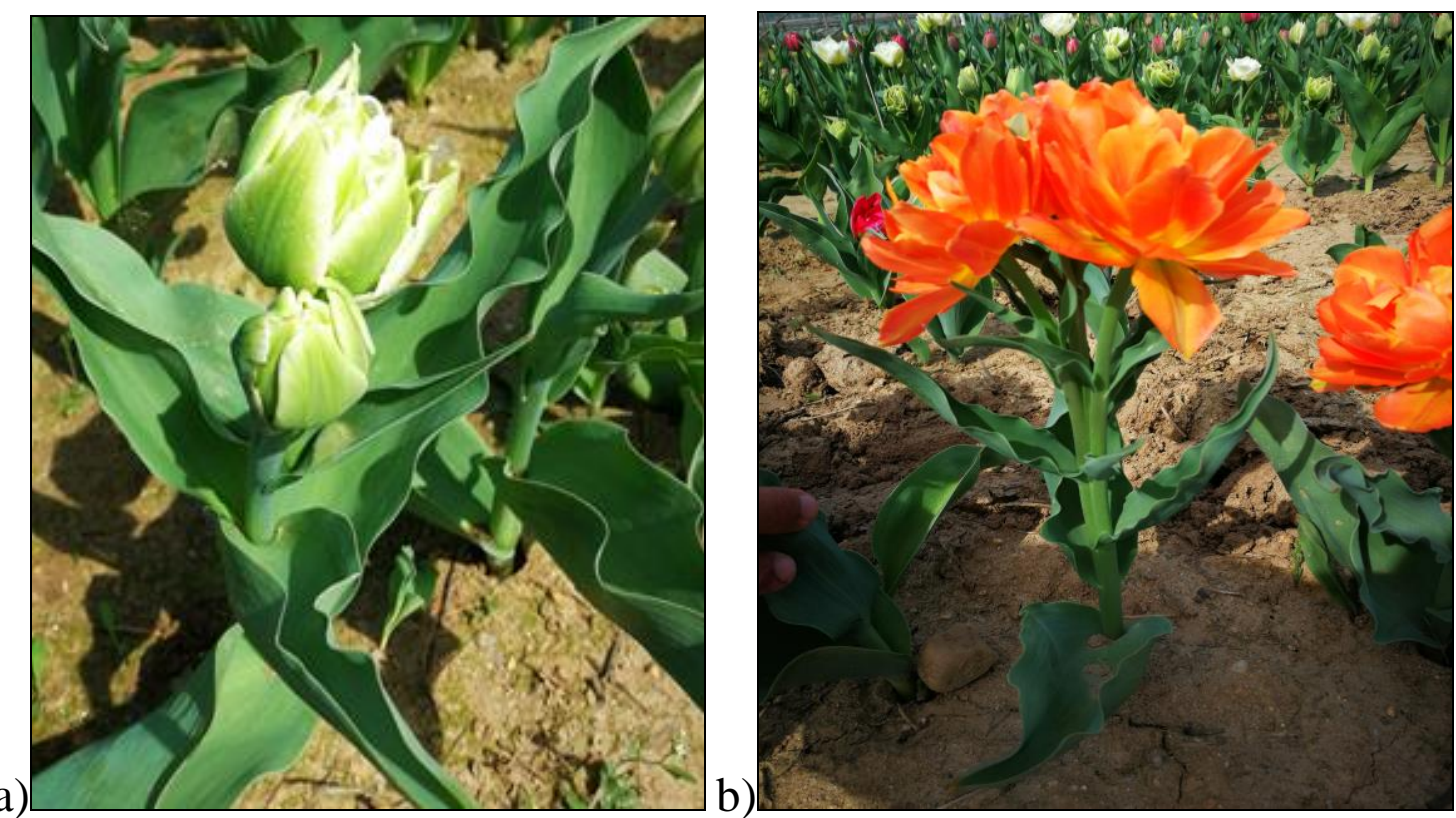

Figure 6. Development of branches at 'Winter Parrot' (a) and 'Irene Parrot' (b) 


\section{Current Trends in Natural Sciences}

Vol. 9, Issue 18, pp. 163-170, 2020

https://doi.org/10.47068/ctns.2020.v9i18.022

Current Trends in Natural Sciences (on-line)

ISSN: 2284-953X

Current Trends in Natural Sciences (CD-Rom)

ISSN: 2284-9521

ISSN-L: 2284-9521

ISSN-L: $2284-9521$

Regarding the lenght of the leaf, in the solarium culture there are no differences between the two cultivars studied. In field cultivation, 'Winter Parrot' obtains the highest value, at the time of harvest $(15.6 \mathrm{~cm})$, (Figure 7).

In terms of leaf width, the same cultivars, 'Winter Parrot' has the highest value, $6.2 \mathrm{~cm}$, in field cultivation (Figure 8).

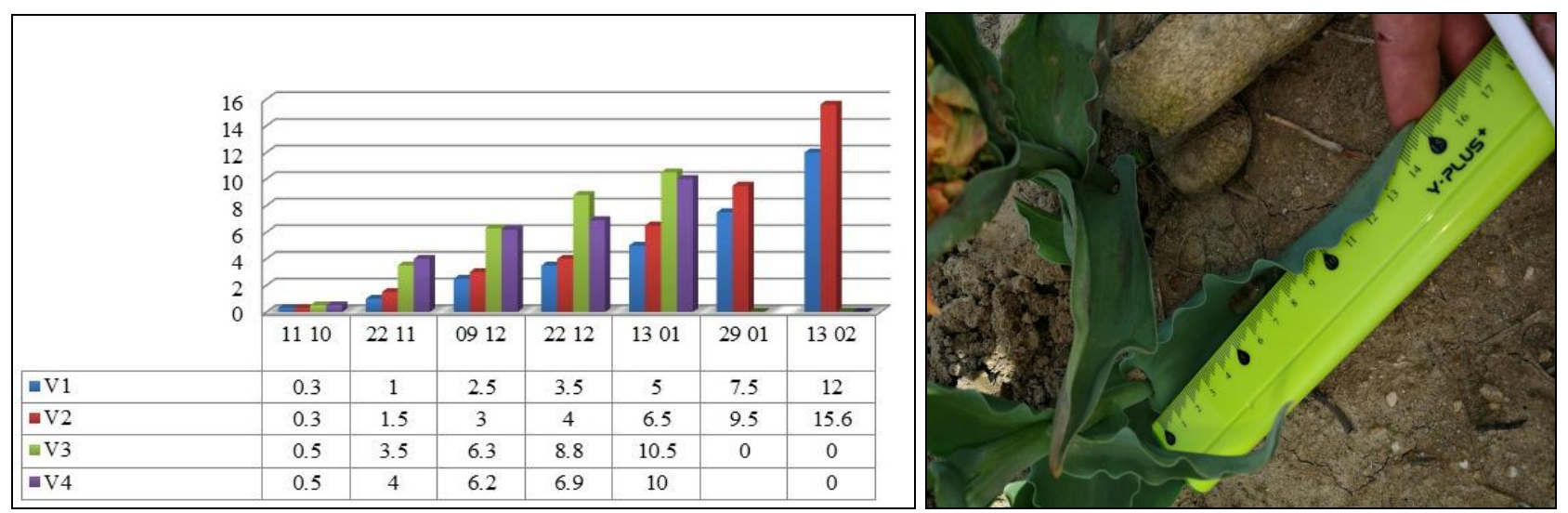

Figure 7. Leaf lenght in the cultivars studied

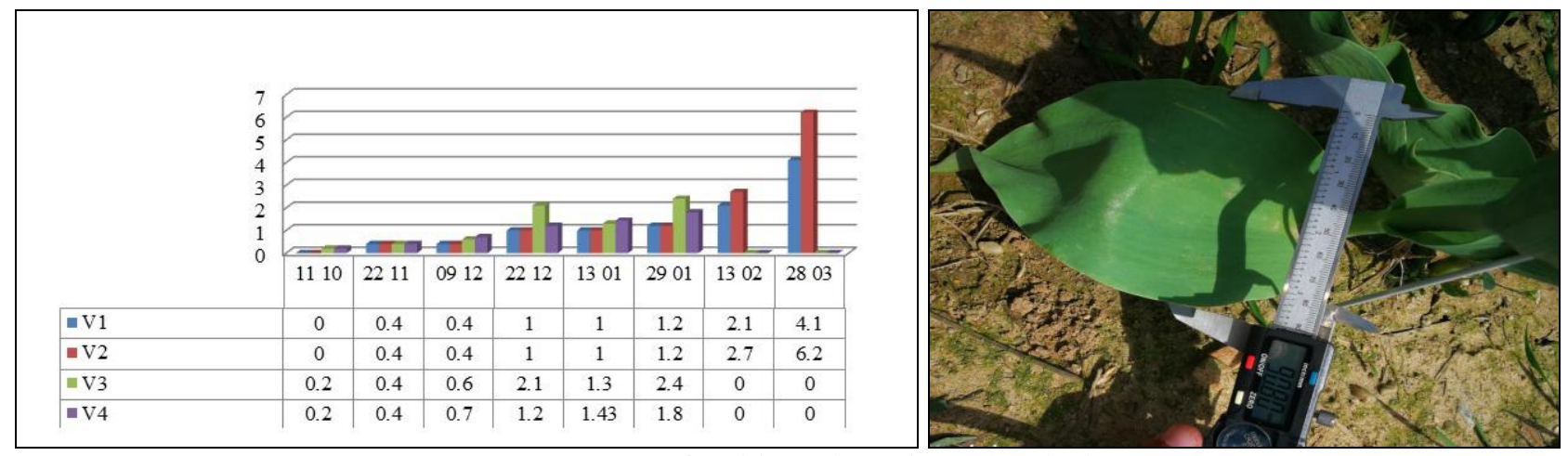

Figure 8. Leaf width in the cultivars studied

In the case of the number of leaves, the highest value belongs to the V1 variant with 5.2 leaves / plant, for 'Irene Parrot' and the lowest value is registered at V4 with only 2.7 leaves / plant, due to the poor development of 'Winter Parrot' (Figure 9).

The cultivar 'Irene Parrot' records the largest diameter of the perigon, $6.5 \mathrm{~cm}$, în the field culture, compared to 3.5 recorded by 'Winter Parrot' in the same conditions (Figure 10).

'Irene Parrot' satnds out in the solarium culture with a diameter of the perigon of $5.5 \mathrm{~cm}$ (Figure $11 \mathrm{a}, \mathrm{b}$ ).

In the case of the perigon lenght, the results are close, in the two types of crops (Figure 12). 'Irene Parrot' records the longest perigon of $4.6 \mathrm{~cm}$ in the field crop (Figure), and 'Winter Parrot', $4.5 \mathrm{~cm}$, in solarium culture (Figure $13 \mathrm{a}, \mathrm{b}$ ). 


\section{Current Trends in Natural Sciences}

Vol. 9, Issue 18, pp. 163-170, 2020

https://doi.org/10.47068/ctns.2020.v9i18.022

Current Trends in Natural Sciences (on-line)

ISSN: 2284-953X

Current Trends in Natural Sciences (CD-Rom)

ISSN: 2284-9521

ISSN-L: 2284-9521

ISSN-L: 2284-9521

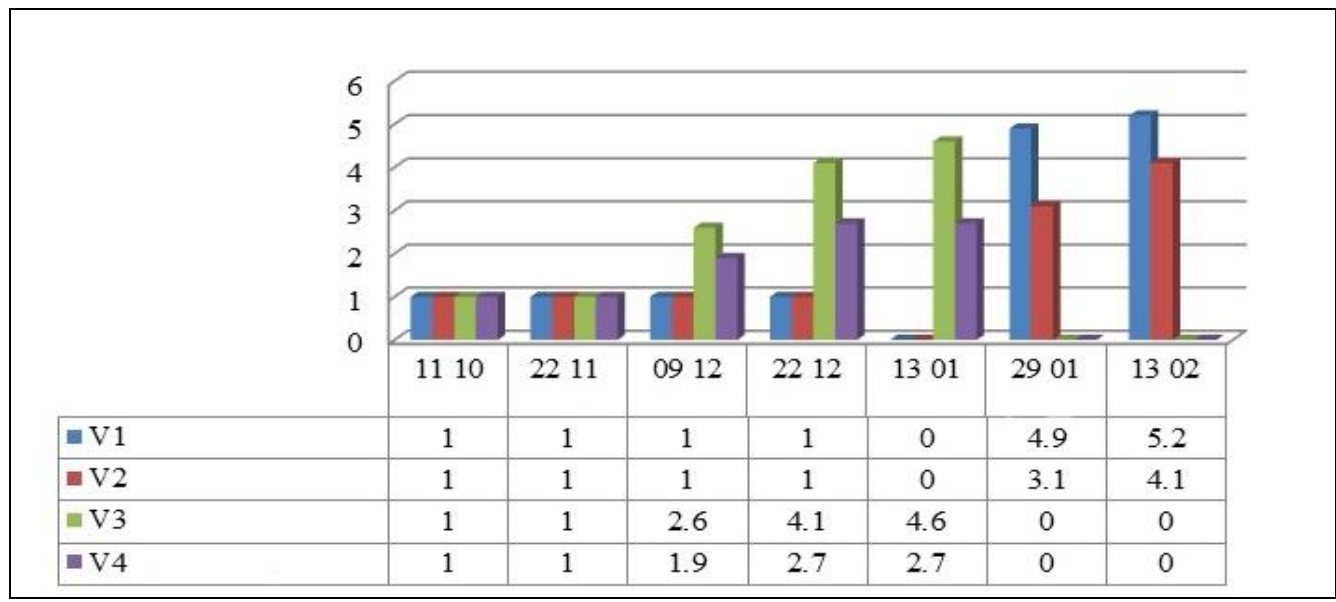

Figure 9. The number of leaves / plant in the studied cultivars

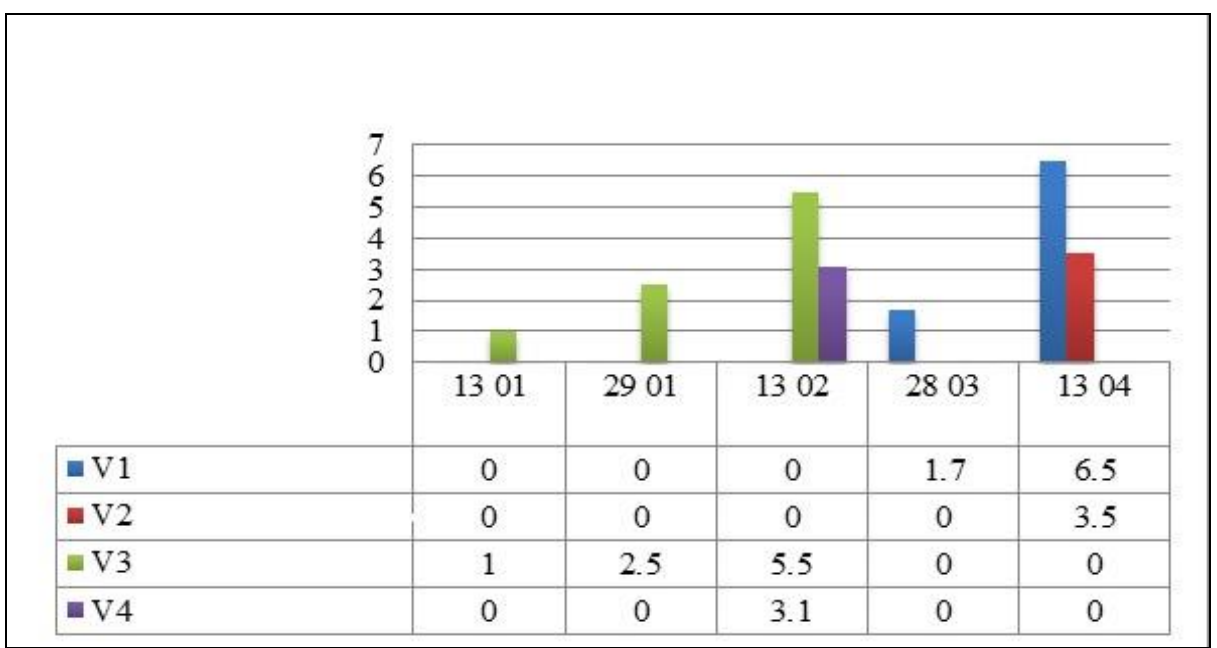

Figure 10. The diameter of the floral cup in the studied cultivars
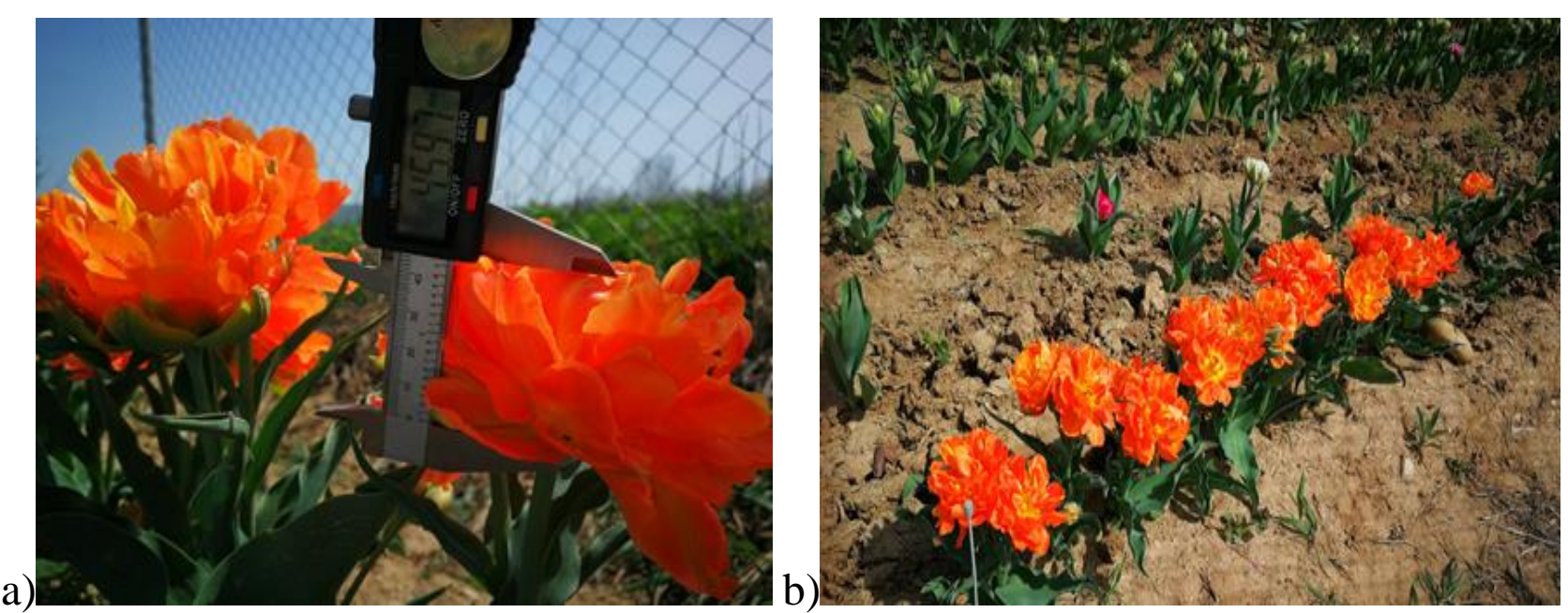

Figure $11(a, b)$. Perigon diameter at 'Irene Parrot' in the field cultures 


\section{Current Trends in Natural Sciences}

Vol. 9, Issue 18, pp. 163-170, 2020

https://doi.org/10.47068/ctns.2020.v9i18.022

Current Trends in Natural Sciences (on-line)

ISSN: 2284-953X

Current Trends in Natural Sciences (CD-Rom)

ISSN: 2284-9521

ISSN-L: 2284-9521

ISSN-L: 2284-9521

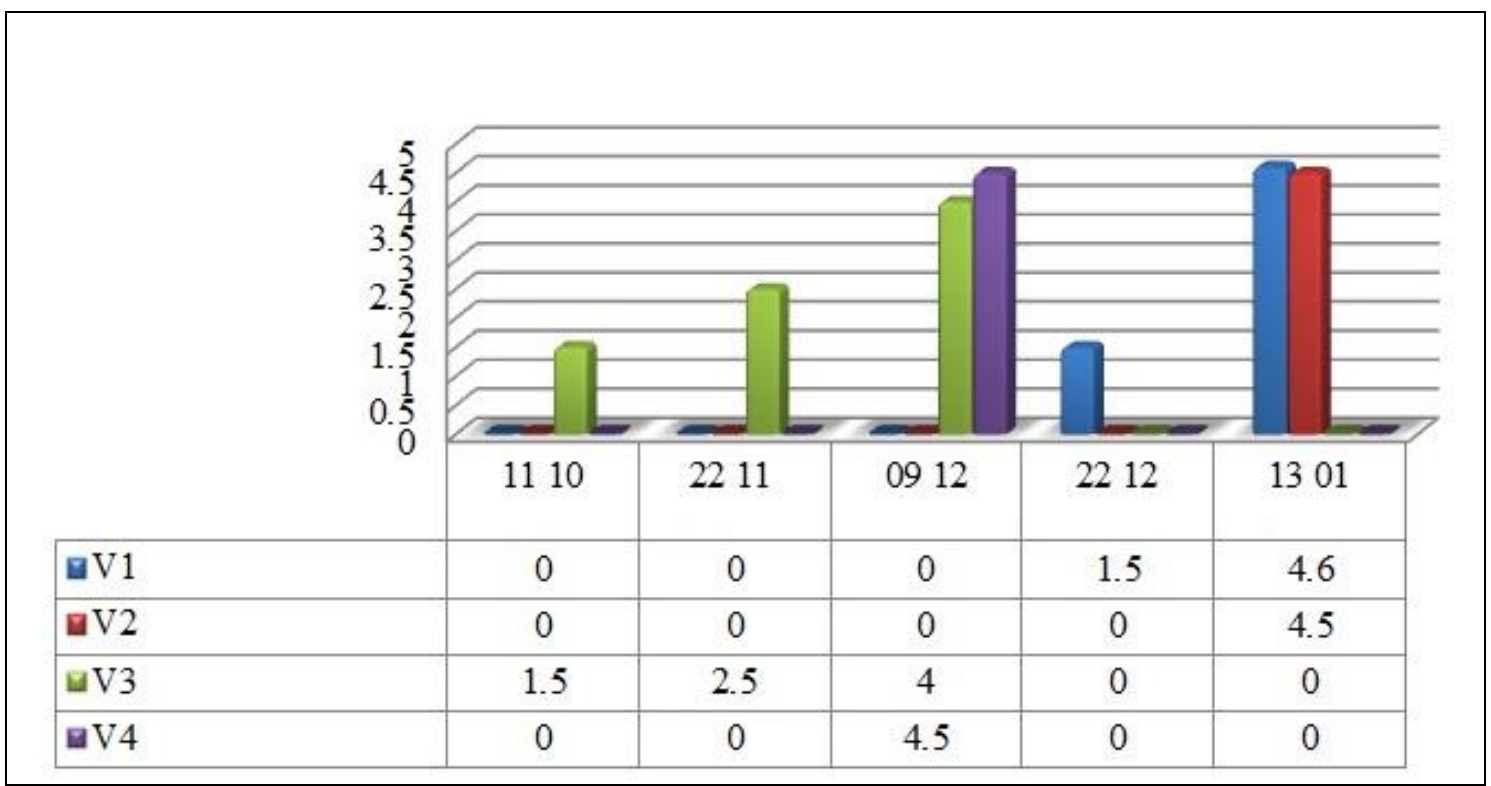

Figure 12. The lenght of the floral cup in the studied cultivars

a)
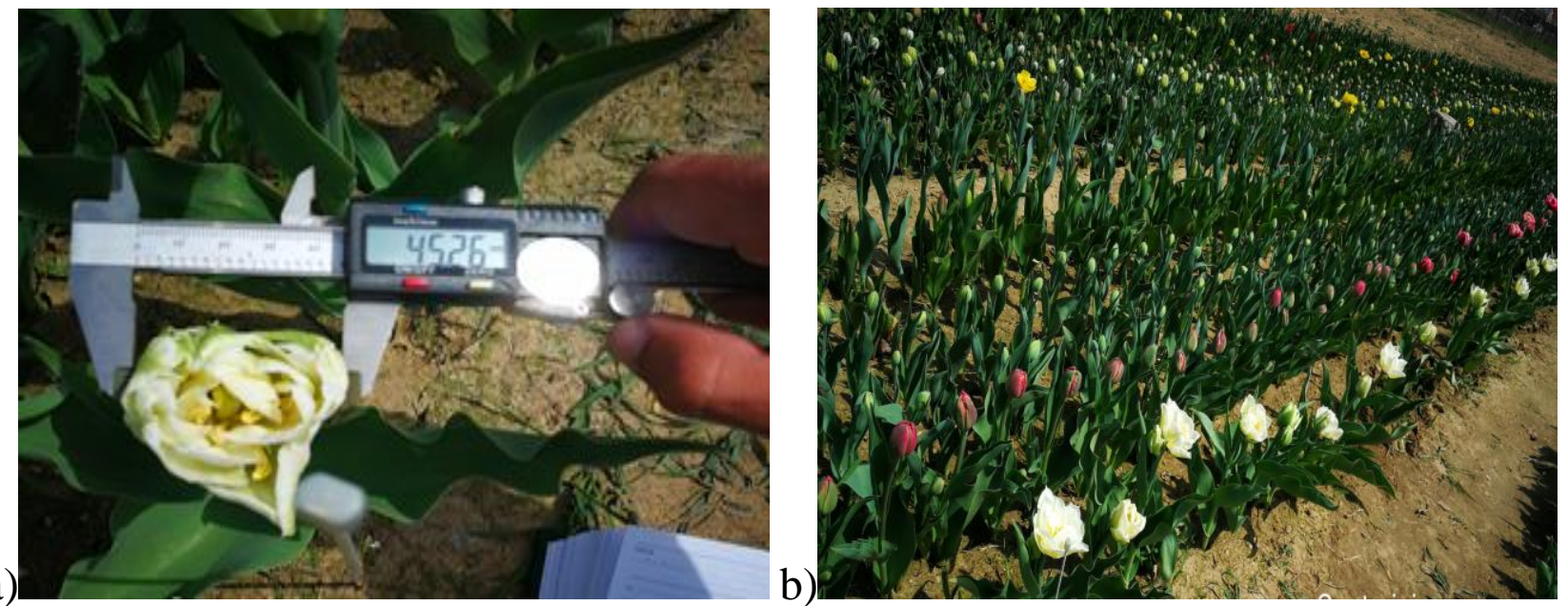

Figure $13(a, b)$. The lenght of the floral cups at the 'Winter Parrot' cultivar in the solarium cultures

\section{CONCLUSIONS}

The low light conditions during the solar culture period greatly influence the increase in height of the studied cultivars, as well as the size and number of leaves, which are lower than in the field culture;

Regarding the characteristics of the floral cup, the negative influence of the low light conditions during the solar culture period is observed;

Tulip cultivations is much profitable in a protected area than in the clasic system culture, because the harvest time is 2 months ahead;

The 2 cultivars do not reach their maximum qualitative potential in protected areas, due to the nonuniformity of growth, but the commercial aspect is not influenced;

Both types of culture are profitable for the Argeș county area. 


\section{Current Trends in Natural Sciences}

Vol. 9, Issue 18, pp. 163-170, 2020

https://doi.org/10.47068/ctns.2020.v9i18.022

Current Trends in Natural Sciences (on-line)

ISSN: 2284-953X

Current Trends in Natural Sciences (CD-Rom)

ISSN: 2284-9521

ISSN-L: 2284-9521

ISSN-L: 2284-9521

\section{REFERENCES}

Ahmad, A., Rehman, S., Hussain, R., Sajjad, R., Sarwar, M., Bashir, A., Khan M.A. (2014). Enhancing the vase life of tulip (Tulipa gesneriana L.) using various pulsing solutions of humic acid and NPK. International journal of plant, animal and environmental sciences, Volume - 4, Issue - 2, ISSN 2231-4490; pp. 193-200.

Bashir, M., Khan, M.A., Qasim, M., Basra S.M.A. (2018). Evaluation of commercial tulip cultivars for flowering potential in climatic conditions of Faisalabad INTERNATIONAL JOURNAL OF AGRICULTURE \& BIOLOGY, Vol 20, No 1, http://www.fspublishers.org.

Cantor, M., Gheorghita, C., (2011). Technological solutions and indoor use of forcing bulb plants, Vol 77, nr.1-2, from http://journals.usamvcluj.ro/index.php/agricultura/article/view/7228.

Oprea, M.I., Duta, M., Concioiu, M.E. (2012), University of Pitești tulip collection, Scientific Papers „Curents Trends in Natural Sciences", University of Pitești, Vol 1/2012, ISSN-L 2284-9521, pp. 136-141.

Selaru, E. (2007). Cultura florilor de grădină [The cultivation of garden flowers].București:Ceres Poublishing House.

Selaru, E. (2007). Culturi pentru flori tăiate [Crops for cut flowers]. București:Ceres Poublishing House.

Sestras, R., Mihalte, L., Sestras, A., Baciu, A., Bondrea, I. (2007). Research regarding the main traits of several genotypes of tulips. J. Agric. Rev. Agricola, 16, 140-145.

Toma, F. (2009). Floricultură generală [General floriculture].Bucureşti:INVEL Poublishing House. 